\title{
A TRADUÇÃO LITERÁRIA: UMA ARTE CONFLITUAL
}

\author{
Brunello De Cusatis \\ Università degli Studi di Perugia \\ decusat@unipg.it
}

Resumo: Sem dúvida que existem diferentes posições, se não mesmo divergentes, em relação à tradução de um "texto aberto" ou literário, sobretudo quando se trata da tradução de um texto poético. Para além do lugar comum da chamada objecção prejudicial - ou seja, o negar a possibilidade de traduzir - que, felizmente, nos dias de hoje foi posta de parte, perdura, entre alguns teóricos, a concepção do tradutor como profissão e, portanto, dotado unicamente de técnica pura. Se uma tal concepção pode - mas só parcialmente e fazendo as devidas distinções - ser aceite com referência à tradução de prosa, absolutamente não se justifica em relação à tradução de poesia. Não fosse senão porque a tradução poética é tão complexa em termos de intertextualidade que representa um dos pontos de tensão mais altos entre as culturas em contacto. Partindo desta premissa, colocamos uma questão: à luz destas dificuldades e dos resultados nem sempre satisfatórios é correcto teorizar, até ao limite extremo, o acto de traduzir, em particular a tradução de poesia?

Palavras-chaves: tradução literária, tradução em prosa, tradução em verso, tradução literária-literal, tradução de arte, tradução bela/infiel, tradução feia/ fiel, tradução-recriação.

\begin{abstract}
Without doubt there are different positions, if not divergent, in relation to the translation of an "open" or literary text, over all, when we speak about a poetical text translation. Apart from the commonplace of the calling objection prejudicial - that is, deny the possibility to translate -, happily nowadays refuse, remain the position of certain theoreticians, that the conception of the translator, as a profession and, therefore, endowed solely with pure technique. If such conception can - but only partially and with the proper distinction - be accepted to the translation of prose, absolutely is not justified in poetical translation. One of the principal motives is
\end{abstract}


that poetical translation is to complex in terms of intertextuality. Based on this preliminary remark we make a question: in the light of these difficulties and of the results not always satisfactory is correct to theorize, until the extreme limit, the act of translation, in special of poetry?

Keywords: literary translation, translation in prose, poetry translation, literary-literal translation, translation up to standard, beautiful translation/unfaithful translation, loyal translation/ugly translation, translation-recreation.

$\mathrm{O}$ argumento que proponho, como se pode facilmente imaginar, é bastante complexo e, simultaneamente, de certo modo ambicioso para poder ser concentrado num artigo ${ }^{1}$. Uma complexidade devida, antes de tudo, à necessidade de fazer, quando se fala de tradução literária, a distinção entre tradução de prosa e tradução de poesia, já que são dois actos da tradução que ocorre considerar separados. De facto, apresentam entre si mais divergências que convergências, sempre que não se trate de prosa alta ou poética, já que neste caso a aproximação entre os dois processos é maior.

Feita esta premissa, procurarei concentrar a referência às peculiaridades mais importantes da tradução literária, quer de prosa, quer de poesia e, portanto, às maiores dificuldades a nível prático ligadas à mesma.

O primeiro aspecto essencial a ter em consideração é a diferença existente entre "texto fechado" e "texto aberto". Tais categorias foram pela primeira vez assim denominadas por Umberto Eco em Opera aperta, de 1962, e posteriormente retomadas e aprofundadas pelo mesmo autor, em 1979, na obra Lector in fabula (Eco, 2006 e 2004).

"Texto fechado" é um texto não literário, ou seja, é um texto que não tem a função de oferecer uma multiplicidade de interpretações a quem o lê. Um texto fechado, por exemplo, é um horário (dos comboios, dos autocarros, dos voos, etc.) ou uma lista telefónica. Produzir um texto deste género não implica, por parte do autor, nenhuma estratégia narrativa, senão aquela implícita de reunir informações precisas que se destinam a ser fornecidas a um "Leitor-modelo", ${ }^{2}$ que é por sua vez igualmente preciso e passivo. 
Escreve Bruno Osimo a respeito disso que "no caso de uma lista telefónica, por exemplo, o leitor-modelo já conhece o uso e a função da rede telefónica, já conhece as modalidades de como o material está organizado no interior do volume e, com toda a certeza, consegue encontrar a informação de que necessita" (Osimo, 1998: 14]. A mesma coisa vale para um horário dos autocarros ou para outro documento do mesmo tipo.

"Texto aberto", pelo contrário, é um qualquer texto literário (em prosa ou em verso), já que neste caso a sua função é a de apresentar - por isto mesmo se chama aberto - inúmeras possibilidades de interpretação a quem o lê. Portanto, no caso de um texto aberto, o leitor não é um fruidor passivo, já que neste tipo de texto lhe é dada uma série, mais ou menos vasta, de hipóteses interpretativas com verificações em anexo, que dependem claramente da sua competência e das suas capacidades inferenciais. ${ }^{3}$

Dito isto, existem, no entanto, lugares comuns, quanto à tradução de um texto aberto ou literário em prosa (mas ainda mais quando se trata da tradução de um texto poético), que devem ser desmontados. À parte o lugar comum da chamada objecção prejudici$a l$ - ou seja, a negação da possibilidade de traduzir $-{ }^{4}$ que felizmente hoje em dia parece ultrapassado de maneira definitiva, perdura ainda, entre alguns teóricos, a concepção do tradutor como profissão e, portanto, dotado unicamente de técnica pura.

Deve dizer-se, para além destes e de outros lugares comuns, que é útil para os leitores que haja tradutores que continuamente e por toda a parte produzam versões de uma determinada obra literária.

O problema é ver e estabelecer como devem ser produzidas tais versões. Por exemplo: a) está certo e compreende-se, no caso da prosa, que possam existir partes do texto da língua de partida não transpostas e, portanto, não traduzidas no texto da língua de chegada?; b) com que base um tradutor pode decidir quais as partes de um texto em prosa na língua de partida que podem não ser transportadas para a língua de chegada?

Um dos maiores teóricos e estudiosos da tradução, o estónio Peeter Torop, escreve na sua célebre obra de 1995 - cujo título em 
português é literalmente $A$ tradução total - que "a tradução absoluta ou ideal não existe, mas, com base num original, pode criar-se toda uma série de traduções diferentes, que são, no entanto, em linha de princípio igualmente válidas" (Cit. in: Idem, 22-23].

O que se obtém desta afirmação? Antes de mais que em qualquer processo de tradução, particularmente na literária, é inevitável a referência a "inter-relações entre elementos traduzíveis, desprezíveis, alteráveis e adicionáveis" (Cit. in: Idem, 23].

Tal processo comporta um facto importante, ou melhor, riscos, entre os quais: a) uma competência linguística ou cultural ou linguístico-cultural do tradutor insuficiente para analisar um texto, o que determinará inevitavelmente erros de compreensão em relação ao texto de partida e, por consequência, também erros de tradução; b) uma intervenção ideológica instrumental activa, quando o tradutor se arroga a pretensão de forçar a versão traduzida à demonstração de uma tese própria.

Com certeza, falando especificamente de prosa literária, uma tradução é válida quando estes tipos de riscos que se apresentam não existem. Igualmente claro é que cada versão de um texto traduzido numa mesma língua difere das outras sobretudo pelo conteúdo, de um ponto de vista tanto conotativo como estilístico. Conteúdo, este, que o tradutor decidiu sacrificar em nome da comunicabilidade, da transposição do texto de partida.

Deste modo, de uma obra literária em prosa, "cada tradução representa a visão do tradutor, parcial, diferente, expressa na língua de chegada, uma visão que também subjectivamente muda com o tempo" (Idem, 23]. Portanto, apesar de o tradutor se esforçar por adoptar a máxima transparência, de se colocar, no seu trabalho de tradução, como um simples mediador entre a obra e o leitor, é natural, quase inevitável, que a sua intervenção de mediação simultaneamente geográfica, histórica, ideológica, cultural e psicológica (seja qual for o grau de intervenção) - acabe por condicionar inevitavelmente o seu trabalho de tradução.

Não é por acaso que o processo da tradução literária é um processo criativo, que as máquinas (os programas de tradução que 
actualmente vários tradutores profissionais utilizam) ainda não são capazes de desenvolver ou fazem-no parcialmente, sendo necessário, no final, a intervenção humana e, portanto, do próprio tradutor (Idem, 23-24].

De resto, como escreve Franco Buffoni:

a tradução literária não pode reduzir-se conceptualmente a uma operação de reprodução de um texto. Isto pode valer quando muito para um texto de tipo técnico, para que é - ao fim e ao cabo - côngruo continuar a falar de descodificação e de recodificação. O nosso conselho, pelo contrário, é o de considerar a tradução literária como um processo, que vê movimentar-se no tempo e - possivelmente - florescer e reflorescer, não "original" e "cópia", mas dois textos providos ambos de dignidade artística (Buffoni, 2005²: 10].

Quando estamos perante um texto literário traduzido, o tradutor assume um papel duplo: o papel de receptor (portanto, de leitor) e o de emitente (portanto, de autor). Substancialmente - como refere Bruno Osimo, que, por sua vez, faz referência a Susan Bassnett-McGuire "o tradutor é fim e início de duas correntes de comunicação diferentes, mas interligadas", que podemos representar com este esquema:

Autor-Texto-Receptor $=$ Tradutor-Texto-Receptor (Osimo, 1998: 27].

Portanto, o tradutor tem toda a responsabilidade do leitor - todavia, a de um leitor particular, já que é um leitor que interpreta o texto de partida, realizando um verdadeiro acto crítico - que se soma à de autor, porque autor do texto na língua de chegada.

Tudo isto faz com que a "arte da tradução" assuma também uma "missão ética", no sentido que lança umas pontes entre culturas estrangeiras, diferentes e distantes, entre os próprios povos, "porque a obra poética e, mais em geral, a obra literária são a 
expressão autêntica de um povo, nunca reprimível nem no decorrer de períodos turbulentos" (Wolfenstein, 2005: 465). Deste modo, os leitores obtêm informações acerca de tudo o que diz respeito a este povo: da conformação do seu território ao seu clima, do seu aspecto corpóreo ao seu espírito, às suas aspirações, da sua história aos seus costumes, à sua cultura em geral:

Seria não natural se à literatura de um povo pudessem ter
acesso só os que falam a mesma língua, se a sua acção tivesse
de parar nas suas fronteiras. Cada obra de arte autêntica tem
um significado humano universal; possui dentro de si a
tendência para se pôr em contacto com a humanidade inteira.
A música, a pintura, a escultura de certeza conseguem fazer
isso. Uma melodia, uma estátua, um quadro não precisam de
intermediário algum. Mas o ouvido e a vista ficam impotentes
perante a língua estrangeira, não obstante um verso possa ter
um seu som absoluto. Aqui deve entrar em acção o tradutor
como segundo autor [...] (Idem). ${ }^{5}$

Um tradutor, todavia, para que seja um bom autor, no momento em que transpõe um texto da língua de partida para a língua de chegada: 1. deve ser muito entendido quer na história quer na cultura do País em que foi produzido o texto em questão; 2. deve possuir um óptimo domínio, pelo menos passivo, da língua de partida, que lhe consinta colher até o recurso a vários artifícios estilísticos e retóricos presentes no texto que tenciona traduzir; 3 . ocorre que conheça e escreva perfeitamente na língua de chegada (neste caso, a competência linguística deve ser absolutamente activa), ainda melhor - sempre no caso específico de uma obra literária em prosa - se é um escritor ou um crítico de profissão, sem, no entanto, se deixar dominar por impulsos narcisistas sob pena de tender a substituir-se ao autor do texto na língua de partida; 4. deve, por fim, dominar as técnicas de escrita, reconhecer os registros linguísticos da língua de partida e saber reproduzi-los na língua de chegada (Osimo, 1998: 28). 
Aqui, porém, surge espontaneamente uma pergunta: no caso, por exemplo, de um grande romance, o tradutor em relação ao autor deve ser de igual para igual? "Deve ser Stendhal ou Tolstoj para poder traduzir La chartreuse de Parme ou Anna Karenina? O violonista ou o pianista não deve ser Mozart quando interpreta as suas grandes óperas. Esta comparação diz-nos que o tradutor é de certeza criativo, mas nos limites da obra em questão" (Wolfenstein, 2005: 469).

Ao mesmo tempo, é claro que a possibilidade de uma maior ou menor adesão ao original depende também do tipo de texto que o tradutor deve enfrentar.

Tenha-se presente além disso que, no interior da vasta gama de textos abertos ou literários a traduzir, há, só para citar alguns: 1. a tradução do texto poético, in primis, que requer - como adiante veremos - uma atenção particular e muito diferente da que é dada a um texto em prosa; 2. a tradução chamada editorial (trabalhar no campo editorial pode significar traduzir quer um romance ou um ensaio, quer um texto jornalístico ou técnico-científico de divulgação); 3. a tradução para o cinema (quer com legendas quer com dobragem); 4. a tradução para o teatro; etc.

Quando se encara a análise de uma obra literária, sobretudo narrativa - um romance, um conto, uma novela - é habitual fazer referência a "sinais de género", tal como são definidos por Umberto Eco - ou seja, aqueles indícios que o autor insere no seu texto de modo que o "Leitor-modelo" tenha a possibilidade de realizar inferências, por outras palavras, que deste texto narrativo possa fazer deduções e tirar conclusões (Eco, 2004: 50-66). No entanto, tais sinais são normalmente dirigidos ao "Leitor-modelo" da língua de partida, o qual, claramente, possui uma "competência enciclopédica" - outra definição de Umberto Eco que significa o conjunto dos conhecimentos do leitor $-{ }^{6}$ diferente em relação ao leitor da mesma obra escrita na língua de chegada.

Estes "sinais de género", por vezes, são ou podem ser reproduzidos no texto de chegada - utilizando, por exemplo, uma locução mais ou menos comprida - outras vezes, o tradutor é obrigado a recorrer a uma nota explicativa. Fundamentalmente, isto ocorre quando não 
se encontra o equivalente para um determinado termo (pode ser até um objecto) ou um determinado modo de dizer (é o caso, por exemplo, de um provérbio) na cultura da língua de chegada.

Em casos de difícil solução, a escolha de inserir uma nota é o meio mais adoptado pelo tradutor, ainda que o menos preferido pelos editores, em particular no interior de uma obra narrativa, como pode ser um livro policial ou um romance de aventuras.

Há, depois, outros casos em que é particularmente impossível manter uma locução ligada à cultura do texto de partida. Um exemplo muito citado é o da locução chinesa "Comeste?", a qual, estranhamente - mas estranhamente para nós, que temos uma cultura tão diferente da chinesa... -, é uma forma de cumprimento. De facto, a insuficiência alimentar é tão importante na história da cultura chinesa que levou à produção desta espécie de locução cuidadosa (Osimo, 1998: 32).

Não há dúvida que a tradução acaba por criar influências, com as suas interpretações mais ou menos certas ou erradas, tanto no leitor quanto, em certos casos, na própria produção literária do País em que tal tradução é comercializada.

Hoje em dia, as tecnologias têm facilitado a aproximação de Países muito distantes. Por consequência, culturas diversíssimas encontram-se entre elas, possibilitando a compreensão não somente da nossa própria cultura mas também a com que se entra em contacto. Quanto mais esta cultura é diferente da nossa mais é precisa a intervenção da tradução, "porque a natureza específica da cultura encontrada pode ser atingida só projectando-a em qualquer coisa de familiar" (Iser, 2005: 505).

Sendo assim, as traduções resultam estar na vanguarda das relações inter-culturais, já que levam a um País estrangeiro uma parte da cultura do País ou dos Países de origem em que o texto ou os textos de partida são produzidos.

Tratemos, agora, especificamente da tradução de poesia, que, como já disse, é um acto de tradução particular, ou seja, diferencia-se - e de modo bastante claro - da tradução em prosa. ${ }^{7}$ 
Jurij M. Lotman, russo de São Pietroburgo, morto em 1993 e um dos representantes máximos no campo da semiótica da cultura - ou seja, a pesquisa semiótica aplicada à metodologia dos estudos literários -, fundador e expoente da Escola Semiótica de Tartu, na Estónia, numa das suas obras mais citadas e estudadas, de 1970 cujo título em português é $A$ estrutura do texto artístico - afirma que "a arte é um dos meios de comunicação". Isto porque ela acaba por determinar "uma ligação entre um transmissor e um receptor", papéis que podem também ser desempenhados pela mesma pessoa - nesse caso estaremos perante um sistema de "autocomunicação" (Lotman, 1990: 13).

Lotman acrescenta que qualquer sistema capaz de colocar em comunicação "dois ou mais indivíduos pode ser definido como língua". Isto, explica ele, não só em relação às línguas "naturais" e às línguas "artificiais", ou seja, em relação às que são criadas pelas diferentes ciências para descrever determinadas fenomenologias - mas igualmente a outras espécies de línguas, tais como, por exemplo, as que dizem respeito aos hábitos, ao comércio, aos rituais, à liturgia. Daí resulta, considerando a presença de tais premissas, que também a arte entra em tal categoria, mesmo que - dá a entender Lotman - de modo autónomo, já que esta é de certeza uma língua, mas uma língua "particular", por ter características próprias que a distinguem dos outros sistemas de comunicação (Idem: 13-14).

Mais adiante, no mesmo ensaio, depois de ter indicado como premissa que por língua ele entende "qualquer sistema de comunicação que empregue signos dispostos numa particular e definida maneira", Lotman escreve:

A linguagem poética apresenta-se como uma estrutura de grande complexidade. Em relação à das línguas naturais, ela é muito mais complicada. E se o volume de informação contido na linguagem poética (em verso ou em prosa: isso não é relevante) e na linguagem corrente fosse igual, a linguagem artística perderia o direito de existir e, indiscutivelmente, 
morreria. A questão coloca-se, porém, de modo diferente: a complexa estrutura artística, criada com o material da língua, permite transmitir um volume de informação que seria absolutamente impossível transmitir com os meios da estrutura linguística normal. Daí resulta que a informação específica (o conteúdo) não pode nem existir nem ser transmitida fora da estrutura específica. Se repetirmos uma poesia na linguagem corrente, destruímos a estrutura e, por conseguinte, já não levamos ao receptor aquele volume de informação que está contido nela (IDEM: 17).

Até aqui Lotman, com quem, por via de regra, se pode concordar, apontando, todavia, algumas reservas. De facto, aplicar à análise de um texto poético - que é um acto de pura criação individual, tal como qualquer expressão artística - uma rigorosa metodologia estrutural, cuja característica principal é o chamado princípio da imanência de saussureana memória (ou seja, a limitação da análise linguística aos enunciados, excluindo por completo as enunciações), comporta o grave risco de pôr em segundo plano, a favor unicamente dos elementos estruturais do texto e da relação que intercorre entre eles, tudo o que é outro. Quer dizer: quanto a quem cria o texto poético, a subjectividade, a consciência, o instinto, a criatividade, a inspiração, as emoções, numa palavra, o vivido do poeta; quanto ao receptor, a sensibilidade, os gostos, as capacidades de interpretação, a cultura, a perspectiva individual, a empatia, as contingências emocionais e situacionais.

O problema, no meu entender, põe-se nestes termos: no momento em que a semiótica acaba por se apresentar como uma teoria geral da cultura peca, pelo menos, por presunção.

É claro que não é minha intenção fazer uma dissertação sobre os factores positivos ou negativos, sobre as vantagens ou desvantagens que comporta a aplicação do estruturalismo linguístico à análise de um texto poético. Quis apenas salientar, referindo algumas afirmações de Lotman, como também aqueles teóricos e estudiosos, cujos métodos de pesquisa se inspiram em sistemas para-científicos 
(tais como os que se relacionam com a semiótica, mas também com a psicolinguística e com a sociolinguística) concordem todos, se não sobre a unicidade da linguagem poética, pelo menos sobre a sua complexidade; características estas que sem dúvida, e como consequência directa, caracterizam também a tradução poética.

Posto isto, surge de imediato uma incógnita: é possível, no sentido etimológico do verbo - do latino traducere -, transportar uns versos e tudo o que os diferencia semanticamente e emocionalmente de uma língua para outra?

Se aceitarmos acriticamente as conclusões a que chegou a linguística contemporânea deveríamos afirmar que não é possível. Estamos perante os mais que conhecidos e velhos conflitos entre teoria e técnica e, sobretudo, entre linguística e estética. E é indiscutível, quanto à tradução poética, que o estudo desta possa ser de pertinência exclusiva da linguística só no caso de a poesia e mais em geral a literatura não serem estudadas na sua especificidade, ou seja, inseridas no grande caldeirão de tudo o que possa ser definível em termos linguísticos.

Tal pretensão hegemónica por parte da linguística foi, no entanto, nas últimas décadas amplamente refutada por muitos estudiosos. É o caso, por exemplo, do oxfordiano George Steiner, que na sua muito citada e, no meu entender, imprescindível obra After Babel. Aspects of language and translation $(1975,1992)$ demonstra os limites da linguística mesmo no campo da chamada tradutologia.

Num verdadeiro ataque frontal contra a linguística contemporânea, e não só relativamente aos delineamentos por ela dada ao problema da tradução, mas, mais em geral, ao uso que ela faz "da palavra e da categoria "teoria" aplicada à poética, à hermenêutica, à estética (e até às ciências sociais)", Steiner escreve:

Não existem "teorias da literatura"; não existe uma "teoria da crítica". Estas fórmulas de moda são somente um bluff arrogante, uma apropriação ilegítima, de uma transparência patética, devida à inveja pelo sucesso e pelo progresso da ciência e da tecnologia. De certo, com licença dos nossos 
maître à penser em bizantinismo, não existem "teorias da tradução". Temos, pelo contrário, descrições reflectidas de procedimentos. Na melhor das hipóteses, encontramos e tentamos articular, alternativamente, narrações de experiência vivida, anotações heurísticas ou ilustrativas de um trabalho in fieri. Estas coisas não têm um estatuto "científico". Os nossos instrumentos de percepção não são teorias ou hipóteses de trabalho num sentido científico que seria verificável ou refutável, mas as que chamo "metáforas de trabalho". As melhores traduções não podem ganhar nada com os diagramas e gráficos computorizados e (matematicamente) pueris propostos por aspirantes teóricos. A tradução é, e sempre será, a que Wittgenstein chama "uma arte exacta" (Steiner, 2004: 16-17).

A conclusão óbvia, portanto, a que se chega é que a tradução poética, para além de ser possível, tem uma sua especificidade.

Às vezes deparamos com traduções mal feitas, o que é devido essencialmente a dois factores. Em primeiro lugar, o texto (já o é o de partida, ainda mais o de chegada!) é sempre caracterizado por conflitos: entre sintaxe e metro, metro e ritmo, som e sentido, etc. Em segundo lugar, a tradução de poesia "é entre os modos da intertextualidade um dos mais complexos e também um dos pontos de tensão mais altos entre culturas em contacto" (Mattioli, 2005²: 215). Não obstante tais dificuldades e os resultados não sempre satisfatórios, julgo, todavia, que se deve a priori recusar - como anteriormente dito - a objecção prejudicial sobre a tradução poética. Ao mesmo tempo, julgo que se deve contestar a tentativa, por parte de muitos críticos e pesquisadores contemporâneos, de teorizar, até ao limite extremo, o acto da tradução, a poética em particular.

Neste ponto, antes de prosseguir, é razoável fazer algumas advertências, duas - para ser mais preciso.

A primeira é que - já se terá intuído pelo que disse até agora - eu suspeito de qualquer teoria ligada à arte de traduzir, em particular quando se trata de poesia. Quando traduzo versos, a minha rota, por assim dizer, é traçada pelo amor que dedico à poesia. Traduzir poe- 
sia, no meu entender, é um acto que não pode ser codificado. É simplesmente "um acto de amor em relação ao poeta e ao seu texto, que comporta sacrifício, dedicação e tempo" (Coco, 1989: 273).

A segunda advertência é que não sou um poeta. Talvez o seja em potência, mas nunca compus versos. Tão pouco sou um filólogo de profissão. O que referi até agora e que continuarei a referir deve-se, portanto, a reflexões, a considerações pessoais, brotadas essencialmente da minha experiência de tradutor. Embora às vezes - e quando isso acontece cito sempre a fonte - sufragadas por testemunhos ou de poetas ou de estudiosos eméritos, interessados nos problemas e nos métodos da tradução.

Ezra Pound, numa sua página sobre a tradução, escreve:

Traduz-se a prosa, talvez, para fazer circular as ideias, mas a poesia dá mais vida. Traduzindo a poesia, estimula-se, enriquece-se a língua, ou pelo menos dever-se-ia. Não encontrando um grande equivalente, mas procurando a precisão, em traduzir uma palavra ou uma frase, amplia-se a língua que a recebe. A tradução põe em evidência o sono, os pontos preguiçosos da língua receptora, e assim desperta-a e agita-a.

De outro modo a língua morre.

Quando Dante precisava de uma palavra não preexistente, fabricava-a. E outros, como ele.

Fabricando uma palavra em caso de necessidade, erra-se, talvez. Mas temendo fabricá-la falha-se, isto é, erra-se inelutavelmente. Este "fazer em caso de necessidade" é completamente diferente de fazer por desejo de criar novidades [...]

Quando se traduz não é preciso que cada palavra corresponda a uma palavra determinada (Cit. in Bona, 1989: 140).

Estas afirmações de Pound, muito iluminantes, fazem reflectir.

De facto, é evidente que o processo de tradução (mesmo no caso de um texto literário em prosa) não é um processo binário, em que a uma palavra da língua de partida deve corresponder uma 
palavra da língua de chegada. É contraditório julgar que o texto de chegada tem de ser igual ao de partida, dado que, por definição, a tradução é deslocação, passagem; ou seja, a imagem que a tradução dá é assintótica e não especular.

Ao mesmo tempo, é indubitável que num contexto poético o tradutor deve chegar ao texto dele conformando-se o mais possível ao do poeta. Numa adesão, todavia, que mantenha implicitamente em si todo o aparato exegético que, a todo o custo, o tradutor deve possuir. Numa palavra, fidelidade, mas não fidelidade asséptica, ou seja, baseada só na transliteração, mas que leve em conta um princípio inegável: qualquer transposição em verso é sempre uma passagem de língua poética para língua poética, visto que - segundo o meu parecer - a condição primordial da tradução poética é a musicalidade, a melodia rítmica.

Tais pressupostos (e não regras - tome-se atenção!), a que, creio, um bom tradutor deve conformar-se, não podem ser codificados. De acordo com George Steiner, estou convencido, portanto, de que não pode existir - em referência à tradução poética, pelo menos - uma teoria, ou pior ainda, uma ciência da tradução. Isto porque, como teve a oportunidade de sublinhar Mário Luzi - um dos maiores poetas italianos contemporâneos, e também ele tradutor (Shakespeare, Coleridge, Labé, Racine, Mallarmé, etc.) -, o acto da tradução poética é um modus operandi puramente empírico (e, eu acrescento, sensitivo, um produto da alma) que não se pode reconduzir a nenhum tipo de teorização, como de resto qualquer obra de arte (Luzi, 1989: 147-148). Creio que ninguém - hoje como ontem e amanhã - pode ou poderá ensinar em que modo se traduz (fazendo-a) poesia, já que a tradução poética está sujeita a motivos de inspiração análogos aos da criação propriamente dita.

Portanto - parafraseando Vittorio Sereni, outro célebre poeta italiano contemporâneo, bem como tradutor apurado do francês (Valéry, Char) e do inglês (Pound, W. C. Williams) -, que sentido tem ao falar-se de tradução literária-literal ou de arte, bela-infiel ou feiafiel? (Sansone, 2005: 487). Este é, fundamentalmente, um falso problema. É evidente que o máximo de aspiração de um tradutor é aportar 
a um texto de chegada belo-fiel. Pergunto-me, no entanto, será isto sempre possível? Creio que não. O que justifica a existência de um elevadíssimo número de traduções coxas, metaforicamente falando, isto é, só com uma perna boa: a da fidelidade ao texto de partida, em algumas, a da beleza do texto de chegada, em outras.

Que fazer então? No que me diz respeito, eu sou pela vibração melódica. Se esta brotar de uma tradução fiel (literária-literal), congratulo-me comigo! Mas se, para consegui-la, devo trair, não tenho a mínima dúvida. Traição, é evidente, sempre numa óptica exegética, e que se realize só a nível de intervenções, por assim dizer, gerais, tais como: a troca de dois lexemas (substantivo e adjectivo, por exemplo) ou de sintagmas ou ainda, se for preciso, de versos inteiros; o recurso à sinonímia e à subtracção ou adição de elementos.

E isto porque uma tradução poética deve estar sujeita a um outro dos seus princípios, o da ars combinatoria, ou melhor, como afirma o inglês Peter Newmark - um dos maiores estudiosos contemporâneos da teoria e prática da tradução e também ele tradutor , na sua já célebre obra, de 1981, Approaches to Translation, “a tradução é sempre um compromisso, a obtenção de um equilíbrio. $\mathrm{O}$ tradutor deve levar em conta o grau de importância nos significados, nas formas e nos sons do seu texto" (Newmark, 1988: 287-288).

Uma outra divaricação - segundo alguns, extrema! -, estritamente correlacionada à anterior divaricação (fidelidade/beleza), é, sempre hoje em dia, a que se relaciona com a tradução métrica, por um lado, e a tradução rítmica (livre), por outro. Também isto, no meu entender, é um falso problema, já que a vibração melódica pode ser conseguida quer com um, quer com outro tipo de tradução.

Todavia, é também evidente que, ao lado deste falso problema, há um problema menos falso. Falo dos sistemas linguísticos, visto que até línguas geneticamente irmãs (é o caso, por exemplo, das línguas italiana e portuguesa) mostram diferenças. O que complica a vida do tradutor quando, querendo forçadamente reproduzir a mesma melodia métrico-rímica (será pois a mesma, pergunto-me?) do texto de partida, encontra-se, não raramente, num beco sem saída. Como - metaforicamente falando - o cobertor curto que 
deixa destapados os pés, se se puxar para cima, a cabeça se se puxar para baixo. Alguém poderia objectar: os cobertores não são todos curtos! É verdade: quando se tem a sorte de encontrá-los...

Chegados aqui, torna-se necessária uma consideração. Está fora de qualquer dúvida que há uma certa diferença entre traduzir de línguas afins e chegadas (é o caso do italiano para o português e vice-versa) e traduzir de línguas diferentes e afastadas (por exemplo, do inglês, do russo ou do japonês - coloquei-as, como se pode notar, por ordem de afastamento - em relação às línguas românicas). Não se quer com isso "subestimar as diferenças, também substanciais, que se interpõem até entre línguas pertencentes à mesma cepa de origem" (Piersanti, 1989: 138). Por exemplo: $a$ flor e a árvore, que em português são substantivos femininos, em italiano são masculinos - il fiore, l'albero -, o que comporta diversidades ao nível de percepção e de tradição cultural. Como não se pode subestimar uma dificuldade que a tradução de uma língua diferente e afastada das nossas não apresenta: a das fáceis semelhanças, dos chamados falsos amigos. Contudo, é indiscutível, "no caso de línguas chegadas, que a aura poética se revele às vezes quase inalterável na mesma transcrição literal" (Idem).

Voltando ao cobertor curto: aqui talvez não seja só uma questão de compromisso, mas, pelo contrário, de escolhas. Pessoalmente, nunca opto por uma tradução métrica com prejuízo para a melodia rítmica e/ou - desta vez sim! - para a fidelidade ao texto de partida.

Resumindo, numa ordem de preferências, pessoalmente ponho: em primeiro lugar, o ritmo e a musicalidade do inteiro corpus poético traduzido; em segundo, a fidelidade lexical (que, uma vez efectuada a escolha rítmica, pode ser mais facilmente respeitada); e só no fim a pura contagem silábica, tendo em consideração as diferenças métricas (por exemplo, o verso alexandrino no sistema português e no italiano). Uma consideração a este respeito: é errado julgar que a tradução livre seja menos absorvente que a métri$\mathrm{ca}$, no sentido que o verso livre (quer quando se cria poesia quer quando se traduz poesia) é - como faz notar Maria Luísa Spaziani, poetisa, francesista e tradutora italiana (Gide, Cocteau, Audiberti, 
etc.) - "mais difícil que o tradicional porque se trata de inventar, de cada vez, uma medida" (Spaziani, 1989: 157).

No entanto, esta ordem de preferências encontra-se posicionada no interior de uma moderada e discreta liberdade em relação ao texto de partida, sem a qual dificilmente o tradutor conseguiria a autenticidade do seu próprio movimento melódico (Sansone, 2005: 497).

Entre as várias classificações, quanto à tradução poética, que nas últimas décadas foram teorizadas figura a do russo Efim Etkind, célebre estudioso de história e teoria da tradução, morto em 1999 em França, onde se tinha estabelecido a partir de 1974, professor na Universidade de Paris-Nanterre e autor de um interessantíssimo ensaio, Un art en crise. Essai de poétique de la traduction poétique, de 1982. Etkind, depois de ter lido "atentamente as edições recentes que os tradutores costumam dotar de prefácios dedicados à ilustração dos princípios a que se inspira o trabalho deles", distingue "seis tipos" de tradução poética (Etkind, 2005: 584-596). Pondo de parte, e deliberadamente, a Tradução-Informação, a Tradução-Alusão e a Tradução-Aproximação (porque, no meu entender, que é pois, no fundo, o mesmo do próprio Etkind, têm pouco ou nada a ver artisticamente com a verdadeira tradução de poesia), vou-me deter rapidamente nas três restantes:

- A Tradução-Interpretação "faz com que a tradução se ligue com a paráfrase e a análise. Ela é útil como suporte aos estudos históricos e estéticos" (IDEM: 584).

- A Tradução-Recriação "recria o conjunto, mantendo porém a estrutura do original. Ela é possível só na presença de sacrifícios, transformações e acréscimos; mas a arte inteira do tradutor consiste mesmo em limitar os sacrifícios ao necessário, em consentir só as transformações que ficam no âmbito específico e restrito do sistema artístico em questão, em fazer unicamente os acréscimos que não ultrapassem os confins do universo estético do poeta" (Idem: 590).

- A Tradução-Imitação produz um afastamento e "introduz uma nova obra num conjunto pertencente mais ao tradutor-poeta que ao autor do original" (Idem: 595). 
Este último tipo de tradução, dizem os peritos (e provavelmente têm razão!), é quase sempre uma opção (talvez genética) dos poetas tradutores, muitos dos quais (quem sabe, talvez por uma solidariedade de categoria!) afirmam que só os poetas podem traduzir os poetas. Refutar um tal preconceito não é difícil.

Karl Dedecius, famoso tradutor alemão das línguas eslavas, na sua obra Vom Übersetzen Theorie und Praxis, de 1986, afirma que o talento poético não exclui nem inclui o da tradução. Isto porque há poetas que, não conseguindo sacudir dos ombros, por assim dizer, o seu próprio estilo, são incapazes de traduzir. De facto, quem escreve poemas nem sempre é um poeta e quem não escreve poemas pode sê-lo em potência (Mattioli, 2005²: 209).

A este respeito, aflora-me à mente uma afirmação de Antero de Quental, que, exprimindo, numa carta de 1888 ao seu amigo Joaquim de Araújo, uma pessoal opinião sobre Tommaso Cannizzaro (poeta siciliano que, em 1898 - portanto depois da morte de Antero - teria vertido para o italiano os Sonetos Completos, uns já anteriormente mostrados a Antero e publicados em revistas e jornais), escreve: "muito livre e mais imitador que propriamente tradutor" (De Cusatis, 1998: 32). E Antero tinha razão! Aliás, ainda no século XIX e durante quase toda a primeira metade do século $\mathrm{XX}$, as traduções italianas em verso, e no caso específico as do português, eram efectuadas não raramente por poetas que, para além de terem muitas vezes pouco domínio da língua estrangeira, antepunham ao rigor filológico da interpretação do texto o rendimento métrico e rímico do verso.

Vejamos, agora, epigraficamente, dois exemplos de tradução poética do português para o italiano.

O primeiro exemplo diz respeito a duas diferentes traduções - à minha e à de Cannizzaro - de um soneto de Antero de Quental, um dos tantos sonetos pessimistas dele, Nocturno. O objectivo é o de mostrar, de um ponto de vista essencialmente operativo, mas não só, o que diferencia a tradução rítmica (que além de favorecer uma maior adesão ao texto de partida, também privilegia a pura 
liberdade melódica) da tradução métrica (onde a contagem silábica e as regras dos acentos prevalecem num diferente quadro de finalidades rítmicas). Uma diferença, portanto, muito importante.

$\mathrm{O}$ texto de partida diz assim:

Espírito que passas, quando o vento

Adormece no mar e surge a Lua, Filho esquivo da noite que flutua, Tu só entendes bem o meu tormento...

Como um canto longínquo - triste e lento Que voga e subtilmente se insinua, Sobre o meu coração, que tumultua, Tu vertes pouco a pouco o esquecimento...

A ti confio o sonho em que me leva Um instinto de luz, rompendo a treva, Buscando, entre visões, o eterno Bem.

E tu entendes o meu mal sem nome, A febre de Ideal, que me consome, Tu só, Génio da Noite, e mais ninguém! (Quental, 1991: 108)

Eis a versão de Cannizzaro:

"Spirto che passi, quando il vento lïeto dorme nel mar cui batte il tremolìo della sorgente luna, o figlio inquïeto della notte, tu sai lo schianto mio.

"Come da lungi voga, e a noi, discreto, giunge un canto in diffuso lamentìo, cosí sul cor che freme irrequïeto a poco a poco tu versi l'oblìo. 
"Io rompo il buio. Il sogno che mi viene dalla luce a te credo, e cerco il Bene de l'Illusione in mezzo a' vasti incendi.

"E tu l'ignoto Mal che in me s'abbica, la febbre d'Ideal che m'affatica, tu solo, o Genio della notte, intendi." (Quental, 1898: 32)

Sem descer a pormenores excessivamente técnicos e dando como adquirido o uso de um léxico típico da época, o que aqui logo ressalta é a perfeita reprodução da forma do texto de partida, a do soneto, com os seus versos decassílabos canónicos e com a única diferença do esquema rímico nas duas quadras: ABBA ABBA no texto de partida, $\mathrm{ABAB}$ ABAB no texto de chegada. O problema, todavia, é que Cannizzaro, por causa desta sua escolha, exagerou, no meu entender, quanto à liberdade. As intervenções, realizadas pelo poeta-tradutor (e não pelo tradutor-poeta!), são de tal modo por conta própria que do texto poético originário restam substancialmente só a forma e o significado geral do soneto; uma tradução, portanto, essencialmente de tipo, segundo a classificação de Etkind, interpretativo e imitativo. Valha como exemplo o primeiro terceto, onde o reviramento é quase total, com o último verso ("de l'Illusione in mezzo a' vasti incendi") criado totalmente por motivos de rima.

Vejamos, agora, a minha tradução, publicada em 1991, junto com a de outros sessenta e oito sonetos anterianos:

"Spirito che passi, quando il vento

S'addorme nel mare e sorge la Luna,

Figlio schivo della notte che fluttua,

Solo tu ben intendi il mio tormento...

"Come un canto lontano - triste e lento -

Che voga e sottilmente s'insinua, 
Nel mio cuore, che tumultua, Tu stilli a poco a poco l'oblio...

"A te affido il sogno in cui m'immette Un istinto di luce, che squarcia il buio, Che cerca, tra visioni, l'eterno Bene.

"E tu intendi il mio male senza nome,

La febbre d'Ideale, che mi consuma,

Solo tu, Genio della Notte, e nessun altro!" (Quental, 1991: 109)

Note-se logo como, diferentemente da tradução de Cannizzaro, esta é uma tradução livremente versificada e literal, que mantém, todavia, um seu específico ritmo e uma sua específica vibração melódica.

O segundo exemplo é extraído de uma antologia bilingue de 1996, publicada na Itália, com o título Versi puri e impuri, que reúne 49 poemas do poeta gaúcho Armindo Trevisan por mim escolhidos e traduzidos. O título é o mesmo daquele de Antero, Noturno:

É sobre a noite que teus seios rugem, pedindo, como leões, o seu sustento:

Penso que pedem a inflação do vento, como o metal à água sua ferrugem.

Enfim, entumescidos como pombos que bicam milho no adro de uma igreja,

eu os comparo a um barco que veleja.

Teus seios são meus ovos de Colombo. (Trevisan, 1996: 104)

a que corresponde: 
"È alla notte che i tuoi seni ruggiscono, chiedendo, come leoni, sostentamento:

"credo che chiedano del vento il gonfiamento, come il metallo all'acqua la sua ruggine.

"Così, intumiditi come colombi che beccano miglio sull'atrio di una chiesa,

"io li comparo a una barca che veleggia.

I tuoi seni sono le mie uova di Colombo." (Idem: 105)

O texto de partida, podemos notar, é formado por quatro dísticos na maioria em versos decassílabos de tipo canónico e com esquema rímico $\mathrm{AB} B \mathrm{BA} \mathrm{CD} \mathrm{DC}$.

Quanto à minha tradução, também neste caso optei por uma versificação livre e substancialmente literal, visto que intervim só no segundo verso (subtraindo o adjectivo possessivo) e no terceiro (trocando a posição dos dois lexemas finais), e sempre em função daquela melodia rítmica que é por mim - como já disse - condição primordial de qualquer tradução poética.

Dito isto, segundo o meu parecer, a liberdade excessiva não compensa. O tradutor deve-se mover em liberdade, mas com moderação. É absolutamente verdade, como afirmou Novalis, que a tradução poética é poesia, mas uma poesia que não deve ser entendida como imitação, nem mesmo como interpretação, mas sobretudo - pelo menos, esta é a minha convicção - como recriação: poesia da poesia. Ficando estabelecido, como anota Peter Newmark, que "provavelmente uma tradução brilhante depende mais da empatia do tradutor com o pensamento do autor que da afinidade linguística e cultural” (Newmark, 1988: 105).

Concluindo, sou da opinião que a tradução poética é uma obra de arte. Esta sua natureza faz com que não se possa estabelecer a priori como deve ser feita. É um erro teorizar um critério que é, pelo 
menos, e absolutamente, empírico (por exemplo, estabelecer, sempre a priori, que forma métrica usar ou se usar qualquer forma métrica): a opção da tradução, pertence, caso por caso, ao tradutor.

\section{Notas}

1. Refiro-me à palestra "Teoria e tecniche della traduzione letteraria", por mim proferida em Assis durante o "II ELI - Encontro de Língua Italiana", realizado, de 20 a 23 de Agosto de 2007, pelo Centro Ítalo-Luso-Brasileiro de Estudos Lingüísticos e Culturais.

2. É importante sublinhar que Umberto Eco, em Lector in fabula, não fala de autor e de leitor "em carne e osso", mas de "Autor-modelo" e de "Leitor-modelo" enquanto "estratégias textuais". O "Autor-modelo" é a estratégia textual utilizada pelo autor empírico para encaminhar no sentido escolhido a actividade cooperante do leitor. O "Leitor-modelo" é "um conjunto de condições de felicidade, textualmente estabelecidas, que devem ser satisfeitas para que um texto seja plenamente actualizado no seu conteúdo potencial”. [Eco, 2004: 50-66 (62)].

3. A inferência, termo filosófico, é aquele processo lógico através do qual, na presença de uma ou mais premissas - no nosso caso específico, na presença de várias interpretações fornecidas pelo autor do texto - é possível extrair uma conclusão, uma dedução, bem como, consequentemente - sempre no caso específico do acto da tradução - fazer com que se crie, no leitor, uma interpretação ou, ainda melhor, um sistema de interpretações, que não é mais do que o acto crítico em si mesmo. Por isso, tal série de propostas de hipóteses e a sua consequente verificação porque se trata justamente, por parte do leitor, de compreender e interpretar tal texto aberto - define-se como "círculo hermenêutico", um conceito, desenvolvido pelo filósofo alemão Hans Georg Gadamer, o pai da hermenêutica contemporânea, que afirma precisamente a circularidade dos processos interpretativos.

4. "Esta posição, presente quer na estética quer na linguística (pense-se em Croce e em Jakobson, só para indicar duas referências muito conhecidas) resulta ligada de um lado a definições essencialísticas da arte e da poesia (para Croce o intraduzível 
deriva da indissolubilidade de conteúdo e forma, para Jakobson do predomínio na poesia da paronomásia) do outro a uma ideia ingénua do processo de tradução, entendido como processo binário em que a uma palavra da língua de partida deve corresponder uma palavra na língua de chegada [...]" [Mattioli, 2005 , 188].

5. É Importante o que refere Wolfgang Iser sobre o "conceito de traduzibilidade", correlacionado com "as variáveis da interpretação" e por ele entendido, justamente, "de vital importância" também quanto ao que "é hoje o interesse principal das doutrinas humanísticas: os cultural studies" [Iser, 2005].

6. A semiótica interpretativa, a que Umberto Eco se refere, afirma que um texto é incompleto sem a intervenção de um leitor que preencha os seus espaços vazios por intermédio da sua actividade inferencial. Um texto - afirma Eco, citando Oswald Ducrot - está "tramado de não-dito", porque deixa implícita uma grande quantidade de informações que o destinatário deve extrapolar segundo o seu conhecimento do contexto comunicativo. Consegue-se isso pressupondo exactamente uma certa "competência enciclopédica" pelo próprio destinatário ou "Leitor-modelo" [Eco, 2004: 50-66 e 76-77].

7. Esta segunda parte representa, naquilo que é o seu núcleo central, o texto de um artigo - agora aqui amplamente revisto e actualizado - por mim publicado em 1997, na revista portalegrense "Continente sul Sur", com o título A tradução poética como ato não codificado [De Cusatis, 1997].

\section{Bibliografia}

BONA, Gian Piero. Interpretes et amants (o la condizione del tradurre), in: BUFFONI, Franco, 1989, 139-143.

BUFFONI, Franco (a cura di). La traduzione del testo poetico. Milano: Guerini e Associati, 1989. 
BUFFONI, Franco (a cura di). Traduttologia. La teoria della traduzione letteraria, “Quaderni di libri e riviste d'Italia”, n 57: Parte I e Parte II, Roma, $2005^{1}$.

BUFFONI, Franco. 2005². Traduttologia, in: BUFFONI, Franco, Parte I, 5-19, $2005^{1}$.

COCO, Emilio. Perché ho tradotto i giovani poeti spagnoli, in: BUFFONI, Franco, 1989, 271-275.

DE CUSATIS, Brunello. A tradução poética como ato não codificado, "Continente sul Sur" (Porto Alegre), no 4, Junho 1997, 91-100.

DE CUSATIS, Brunello. A Itália em Antero. Antero em Itália, "Estudos Anterianos" (Vila do Conde), $\mathrm{n}^{\mathrm{O}}$ 2, Outubro de 1998, 23-33.

ECO, Umberto. (IX edizione). Lector in fabula. La cooperazione interpretativa nei testi narrativi. Milano, Tascabili Bompiani, 2004.

ECO, Umberto. (VII edizione). Opera aperta. Forma e indeterminazione nelle poetiche contemporanee. Milano, Tascabili Bompiani, 2006.

ETKIND, Efim. Un'arte in crisi. Saggio di poetica della traduzione (Qual è lo scopo della traduzione poetica?), in: BUFFONI, Franco, 2005 ${ }^{1}$, Parte II, 561599.

ISER, Wolfgang. Il concetto di traducibilità: le variabili dell'interpretazione, in: BUFFONI, Franco, 2005' ${ }^{1}$ Parte II, 505-519.

LOTMAN, Jurij M. (ed. orig.: 1970; I ed. italiana 1972). La struttura del testo poetico, a cura di Eridano Bazzarelli. Milano: Mursia, 1990.

LUZI, Mario. Riflessioni sulla traduzione, in: BUFFONI, Franco, 1989, 145149.

MATTIOLI, Emilio. La traduzione letteraria, in: BUFFONI, Franco, 2005 Parte I, 187-198. 
MATTIOLI, Emilio, 2005². La traduzione di poesia come problema teorico, in: Buffoni, Franco, 2005', Parte I, 205-215.

NEWMARK, Peter. (ed. e tit. orig.: Approaches to Translation, 1981). La traduzione: problemi e metodi. Milano: Garzanti, 1988.

OSIMO, Bruno. Manuale del traduttore. Guida pratica con glossario. Milano: Editore Ulrico Hoepli, 1998.

PIERSANTI, Umberto. Il testo non è pretesto, in: BUFFONI, Franco, 1989, 135-138.

QUENTAL, Antero de. Sonetti completi. Prima versione italiana pubblicata dall'autore (Tommaso Cannizzaro) di Fiore d'oltralpe, eseguita dallo stesso e da Giuseppe Zuppone Strani [...]. Messina: Tipi dell’Editore, 1898.

QUENTAL, Antero de. Sonetti. Introduzione, traduzione e note di Brunello De Cusatis. Palermo: Novecento, 1991.

SANSONE, Giuseppe E. Traduzione ritmica e traduzione metrica, in: BUFFONI, Franco, 2005' ${ }^{1}$, Parte II, 2005, 487-503.

SPAZIANI, Maria Luisa, 1989. La traduzione di poesia come osmosi, in: BUFFONI, Franco, 1989, 151-157.

STEINER, George, 2004 (ed. e tit. orig.: After Babel. Aspects of language and translation, 1992, nova versão revista, actualizada e ampliada relativamente à de 1975). Dopo Babele. Aspetti del linguaggio e della traduzione. Milano, Garzanti.

TREVISAN, Armindo, 1996. Versi puri e impuri. Antologia poetica, a cura di Brunello De Cusatis. Roma, Antonio Pellicani Editore.

WOLFENSTEIN, Alfred, 2005. L'arte della traduzione, in: BUFFONI, Franco, 2005' , Parte II, 465-470. 